УДК 614.258:656.2(477)

\title{
КОНЦЕПТУАЛЬНІ ПОЛОЖЕННЯ РОЗВИТКУ ЗАКЛАДІВ ОХОРОНИ ЗДОРОВ'Я АТ «УКРАЇНСЬКА ЗАЛІЗНИЦЯ»
}

\author{
Головаш О.В., здобувач (УкрДУЗТ)
}

\begin{abstract}
В статті розкрито концептуальні положення розвитку закладів охорони здоров'я АТ «Українська залізниця». В основу концепції покладено виділення пріоритетних напрямків розвитку, орієнтованих на отримання максимального та довгострокового економічного ефекту, активізація інновачійних та інвестиційних прочесів в закладах охорони здоров'я. Ключовими інструментами розвитку медичних закладів визначено інноваџійний, інвестиційний потенціали закладів, потенціал розвитку, інтеграційні зв'язки між профільними науковими, науково-виробничими установами та закладами, трансферт інновачій у лікувально-діагностичний процес, Центр інновачійних медичних технологій, Інвестиційний фонд розвитку закладів хорони здоров'я.
\end{abstract}

Ключові слова: заклади охорони здоров'я, розвиток, лікувально-діагностичний процес, АТ «Украӥнська залізниця», інформаційне забезпечення.

\section{КОНЦЕПТУАЛЬНЫЕ ПОЛОЖЕНИЯ РАЗВИТИЯ УЧРЕЖДЕНИЙ ЗДРАВООХРАНЕНИЯ АО «УКРАИНСКАЯ ЖЕЛЕЗНАЯ ДОРОГА»}

\author{
Головаш А.В., соискатель (УкрГУЖТ)
}

В статье раскрыто концептуальные положения развития учреждений здравоохранения $A O$ «Украинская железная дорога». В основу кониепџии положено выделение приоритетных направлений развития, ориентированных на получение максимальной и долгосрочного экономического эффекта, активизаџия инновационньхх и инвестиционных процессов в учреждениях здравоохранения. Ключевыми инструментами развития медицинских учреждений определен инновационный, инвестиционный потенциаль заведений, потенциал развития, интеграционные связи между профильными научными, научно-производственньли учреждениями, трансферт инноваций в лечебно-диагностический процесс, Центр инновационных медицинских технологий, Инвестиционный фонд развития учреждений зравоохранения.

Ключевые слова: учреждения здравоохранения, развитие, лечебнодиагностический процесс, АО «Украинская экелезная дорога», информационное обеспечение.

\section{CONCEPTUAL PROVISIONS OF THE DEVELOPMENT OF HEALTH INSTITUTIONS OF UKRAINIAN RAILWAY JSC}

\section{Holovash O., Applicant (USURT)}

The article describes the conceptual provisions of the development of health facilities of JSC Ukrainian Railways. the concept is based on the priority areas of development, 
focused on maximizing and long-term economic impact, activation of innovation and investment processes in health care institutions.

The key directions of development of health care institutions are improvement of the medical-diagnostic process, organizational-management system and information support system.

The modernization of the information support system should be based on the provision of technical support to health care facilities, support for clinical activities, administrative and economic activities and concentration of information around the patient. This can be achieved through the organization of a single information space, the introduction of an electronic medical card and services to access it using service-oriented technologies.

The conceptual provisions of the development of health facilities of JSC "Ukrainian Railways" are proposed, which, unlike the existing ones, are based on the allocation of strategic goals and objectives in accordance with the strategic directions of the industry development, determination of legal, organizational, managerial, socio-cultural, innovative and investment development tools (innovative, investment potentials of institutions, development potential, integration links between specialized scientific, research and production institutions and institutions, transfer Innovations in medical diagnostic process, the Center for Innovative Medical Technologies, Investment Development Fund Keep health institutions), to form a set of measures of health care.

Keywords: healthcare institutions, development, diagnostic and treatment process, JSC Ukrainian Railways, information support.

Постановка проблеми. Однією 3 найважливіших складових частин соціальної сфери залізничного транспорту $\epsilon$ організація медичного обслуговування залізничників і їхніх родин. Робота медичних установ на транспорті набуває особливу відповідальність, оскільки від стану здоров'я працівників залежить не тільки якість і ефективність виконуваної роботи, але i безпеку руху поїздів i безаварійність роботи всього транспорту. Реорганізація АТ «Українська залізниця» та оптимізація соціальних об'єктів потребують формування нових концептуальних положень розвитку медичних закладів, що входять до АТ «Українська залізниця».
Аналіз

Проблемам

розвитку

розвитку

сфери,

останніх

досліджень інфраструктури підприємств присвячено роботи вітчизняних та зарубіжних вчених: Гринько О., Дикань В.Л., Дудов А. С., Каличева Н. С., Компанієць В.В., Корінь М.В., Крючков М.Т., Конов А.А.,
Кучин С. П., Летуновська Н.С., Матвієнко В.В., Тимошенко М.М., Токарчук Д.М., Шашман А.М., Шишин С.О. та ін.[1-14]. Однак основна увага науковців була зосереджена на питаннях соціальної відповідальності підприємств залізничного транспорту. Крім того, в сучасних умовах реформування системи охорони здоров'я України виникає необхідність більш глибокого дослідження питань та розробки положень щодо розвитку закладів охорони здоров'я АТ «Українські залізниці».

Метою статті $\epsilon$ формування концептуальних положень розвитку закладів охорони здоров’я АТ «Українська залізниця».

Виклад основного матеріалу. В умовах реорганізації АТ «Українська залізниця» та створення бізнес сегментів заклади охорони здоров'я було підпорядковано Філії "Центр охорони здоров'я" АТ “Укрзалізниця", основним завданням якої $\epsilon$ надання медичних послуги залізничникам, членам їхніх родин, пасажирам залізничного транспорту та всім громадянам України. 
До складу філії входять 8 клінічних лікарень в Києві, Харкові, Одесі, Львові, Дніпрі. Протягом останніх років медичні заклади залізниці активно співпрацюють зі страховими компаніями за програмами добровільного медичного страхування, що дозволяє покращити фінансування та забезпечувати на належному рівні надання медичних послуг застрахованим залізничникам.

В умовах реформування системи охорони здоров'я України розвиток Центру охорони здоров’я АТ «Українська залізниця» та закладів, що входять до його структури потребують формування нової концепції подальшого розвитку.

Концепція розвитку закладів охорони здоров'я АТ «Українська залізниця» повинна базуватися на визначених стратегічних напрямках розвитку АТ. Так досягнення стратегічної мети - підвищення рівня безпеки на залізничному транспорті та дотримання стандартів охорони здоров'я та безпеки співробітників відповідно до міжнародних практик доцільно здійснювати шляхом удосконалення системи надання медичних послуг (лікувально-діагностичного процесу), модернізації системи інформаційного забезпечення, удосконалення системи фінансування (рис.).

Ключовими напрямами розвитку закладів охорони здоров'я $\epsilon$ удосконалення лікувально-діагностичного процесу, організаційно-управлінської системи та системи інформаційного забезпечення.

Удосконалення системи надання медичних послуг (профілактика, діагностика, лікування та реабілітація) доцільно здійснювати за основі:

розробки нових методів ведення лікувально-діагностичного процесу;
- розробки i впровадженню програми розвитку матеріально-технічної бази закладів охорони здоров'я;

- підвищення кваліфікації працівників;

- впровадження системи новітніх стандартів надання медичних послуг;

- персоналізації медицини.

Основними інструментами удосконалення системи надання медичних послуг $є$ безпосередня технічна модернізація медичних закладів та впровадження навігаційних телекомунікаційних технологій для надання медичної допомоги.

Удосконалення організаційноуправлінської системи передбачає:

- удосконалення

системи фінансування закладів охорони здоров'я, формування нових джерел фінансування;

- розробку індикативних показників, які дозволять визначати рівень розвитку закладу;

- створення цільових проектів та програм розвитку закладів охорони здоров'я;

- створення інноваційних структур, активізація взаємодії наукового потенціалу медичної галузі 3 закладами охорони здоров'я АТ «Українська залізниця»;

- технічна модернізація закладів. Модернізація

системи інформаційного забезпечення повинна базуватися на забезпеченні технічної підтримки закладів охорони здоров'я, підтримці клінічної діяльності, адміністративно-господарської діяльності та концентрації інформації навколо пацієнта. Цього можливо досягти за рахунок організації єдиного інформаційного простору, впровадження електронної медичної карти та сервісів доступу до неї з використанням сервісноорієнтованих технологій. 


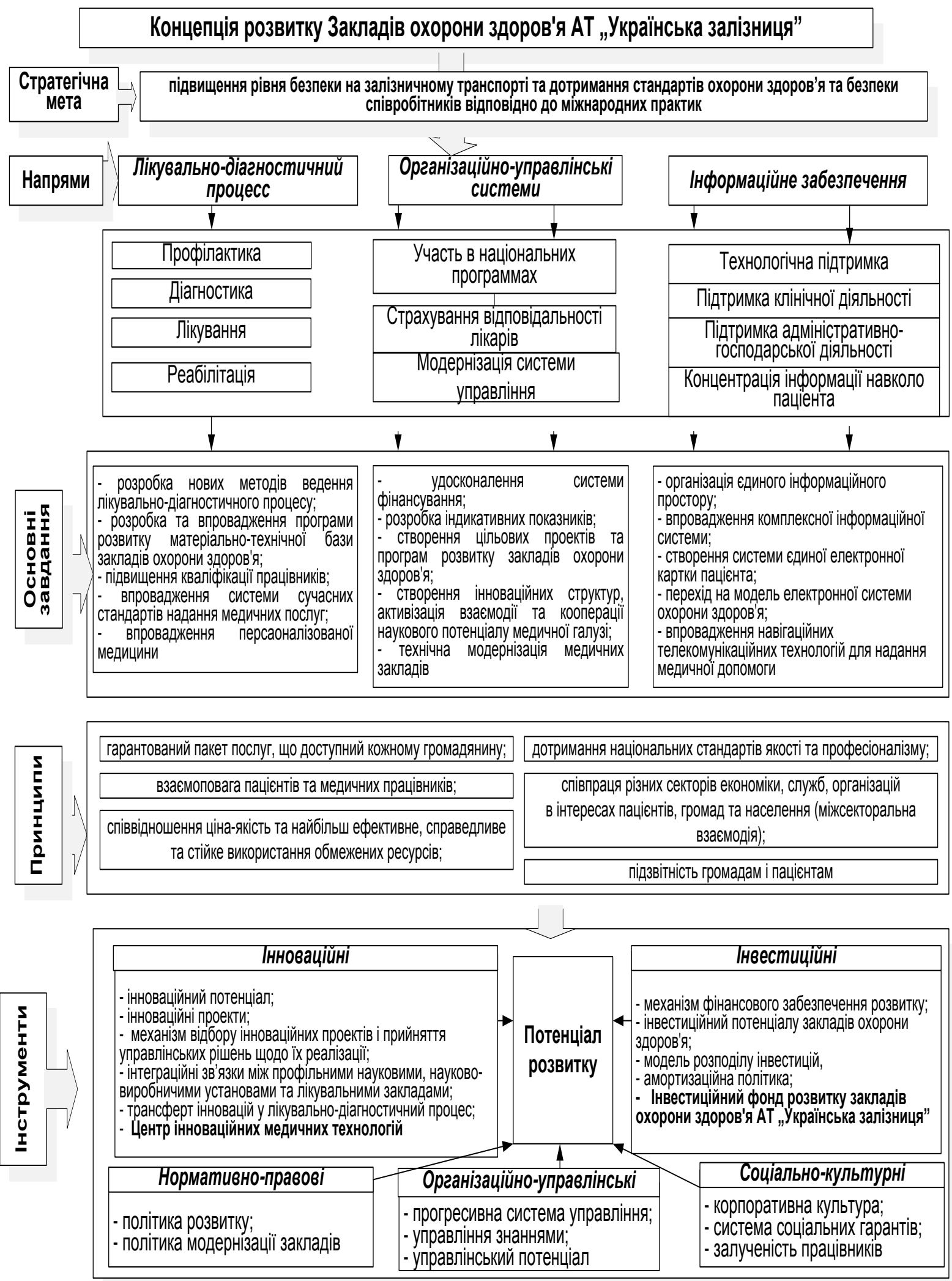

Рис. Конщептуальні положення розвитку закладів охорони здоров'я АT «Українська залізницяя 
Ключовими принципами на яких повинен базуватися механізм подальшого розвитку закладів охорони здоров'я $\epsilon$ :

гарантований пакет послуг, що

доступний кожному громадянину;

- дотримання національних

стандартів якості та професіоналізму;

- взаємоповага пацієнтів та

медичних працівників;

- співпраця різних секторів

економіки, служб, організацій в інтересах пацієнтів, громад та населення

(міжсекторальна взаємодія);

- співвідношення ціна-якість та

найбільш ефективне, справедливе та

стійке використання обмежених ресурсів;

- підзвітність громадам

пацієнтам.

Інструменти розвитку закладів

охорони здоров'я пропонуємо поділити на групи:

$\begin{array}{ccc}\text { - інноваційні }- & \text { включають } \\ \text { інноваційний потенціал } & \text { закладів, }\end{array}$ інноваційні проекти, механізм відбору інноваційних проектів і прийняття управлінських рішень щодо їх реалізації, інтеграційні зв'язки між профільними науковими, науково-виробничими установами та закладами охорони здоров'я, трансферт інновацій у лікувальнодіагностичний процес, Центр інноваційних медичних техноологій;

- інвестиційні

механізм

інвестиційного забезпечення розвитку, інвестиційний потенціал закладів, модель розподілу інвестицій, амортизаційна політика та Інвестиційний фонд розвитку медичних закладів;

- нормативно-правові - політика розвитку, політика модернізації закладів;

- організаційно-управлінські -

прогресивна система управління, управління знаннями; управлінський потенціал;

- соціально-культурні

корпоративна культура,

соціальних гарантій,

працівників.
Реалізація стратегічних напрямків розвитку закладів охорони здоров'я, впровадження зазначеного інструментарію та формування механізму реалізації необхідних заходів буде визначатися i здійснюватися в межах стратегії розвитку закладів охорони здоров'я.

Таким чином, в основу концепції покладено виділення пріоритетних напрямків розвитку, орієнтованих на отримання максимального та довгострокового економічного ефекту (напрямків пов'язаних 3 удосконаленням лікувально-діагностичного процесу, організаційно-управлінської системи та системи інформаційного забезпечення), активізація інноваційних та інвестиційних процесів в закладах охорони здоров'я. Реалізація зазначеної концепції дозволить активізувати потенціал розвитку закладів, модернізувати лікувально-діагностичний процес, налагодити механізм створення та впровадження у виробництво інноваційного продукту і послуг, перейти закладам охорони здоров'я на якісно новий рівень.

Висновки. Запропоновані концептуальні положення розвитку закладів охорони здоров’я АТ «Українська залізниця», що, на відміну від існуючих, грунтуються на виділенні стратегічних цілей і завдань відповідно до стратегічних напрямків розвитку галузі, визначенні правових, організаційно-управлінських, соціально-культурних, інноваційних та інвестиційних інструментів розвитку (інноваційний, інвестиційний потенціали закладів, потенціал розвитку, інтеграційні зв'язки між профільними науковими, науково-виробничими установами та закладами, трансферт інновацій у лікувально-діагностичний процес, Центр інноваційних медичних технологій, Інвестиційний фонд розвитку закладів хорони здоров'я), що забезпечує формування комплексу заходів розвитку закладів охорони здоров'я. 
ПЕРЕЛІК ВИКОРИСТАНИХ ДЖЕРЕЛ

1. Гринько

О. Вплив соціальної інфраструктури на розвиток виробництва в регіоні / О. Гринько. - Режим доступу: http://oldconf.neasmo.org.ua/node/1113

2. Дикань, В. Л. Етичні основи бізнесу: навч. посіб. для студ. вищ. навч. закл. / В. Л. Дикань, В. В. Компанієць, О. М. Полякова ; Укр. держ. акад. залізн. трансп. - Х. :УкрДАЗТ, 2012. - 316 с.

3. Дудов А. С. Социальная инфраструктура предприятий в современных условиях / А. С. Дудов. Режим доступу: https://cyberleninka.ru/article/n/sotsialnayainfrastruktura-predpriyatiy-v-sovremennyhusloviyah

4. Каличева Н. Є. Вплив соціальної відповідальності на ефективний розвиток підприємств залізничного транспорту / Н. С. Каличева, М. К. Ампілогов // Проблеми системного підходу в економіці. - 2018. Вип. 2. - С. 53-57.

5. Компанієць В.В. Соціальна відповідальність на залізничному транспорті України: щодо оцінки наслідків реформування та механізму забезпечення / В.В. Компанієць // Вісник економіки транспорту і промисловості. 2016. - № 55. - С. 151-161

6. Корінь М.В. Соціальний розвиток колективу ПАТ «Українська залізниця» в умовах реформування галузі: наслідки та елементи забезпечення / М.В. Корінь. Режим доступу: https://cyberleninka.ru/article/n/sotsialniyrozvitok-kolektivu-pat-ukrayinskazaliznitsya-v-umovah-reformuvannya-galuzinaslidki-ta-elementi-zabezpechennya

7. Крючков М.Т. Развитие социокультурной инфраструктуры железнодорожного транспорта на Урале / М.Т.Крючков, А.А.Конов. - Режим доступа: https://www.fundamentalresearch.ru/ru/issue/view?id=498

8. Кучин С. П. Сутність та динаміка розвитку соціальнокультурної інфраструктури в Україні як об'єкту державного регулювання / С. П. Кучин. Режим доступу: http://www.investplan.com.ua/pdf/1_2017/17 .pdf

9. Летуновська Н. Є. Соціальна інфраструктура промислового підприємства та іï значення в системі мотивації персоналу / Н.С. Летуновська. Режим доступу: http://mmi.fem.sumdu.edu.ua/sites/default/fil es/mmi2014_1_259_269.pdf

10. Матвієнко В. В. Оцінка та перспективи розвитку залізничної галузі в україні / В.В. Матвієнко // Державне управління: удосконалення та розвиток. 2016. - № 8 - Режим доступу: http://www.dy.nayka.com.ua/?op=1\&z=994

11. Тимошенко M. M. Теоретичні засади розвитку соціальної інфраструктури сільських територій/ М.М. Тимошенко // Ефективна економіка. 2014. - № 11. - Режим доступу: http://www.economy.nayka.com.ua/?op=1\&z $=3501$

12. Токарчук Д.М. Сучасний стан та перспективи розвитку соціальновиробничої інфраструктури села / Д.М. Токарчук. - Режим доступу: http://econjournal.vsau.org/files/pdfa/241.pdf

13. Шашман A.M. Сутність соціальної інфраструктури підприємства та іiї вплив на ефективність виробництва / A.M. Шашман. - Режим доступу: http://www.rusnauka.com/9_DN_2010/Econ omics/62574.doc.htm

14. Шишин С. О. Исследование общего и особенного в формировании социальной инфраструктуры предприятий и административных территорий [Текст] // Экономика, управление, финансы: материалы V Междунар. науч. конф. (г. Краснодар, август 2015 г.). - Краснодар: Новация, 2015. - C. 114-118. - URL https://moluch.ru/conf/econ/archive/204/8602

\section{REFERENCES}

1. Grinko O. Influence of social infrastructure on the development of 
production in the region. URL: Object of State Regulation URL: http://oldconf.neasmo.org.ua/node/1113

2. Dykanj, V. L.(2012) Etychni osnovy biznesu: navch. posib. dlja stud. vyshh. navch. zakl. [Ethical Foundations of Business: Tutorial. tool. for students. higher. teach. closed] Ukr. derzh. akad. zalizn. transp. - Kh. :UkrDAZT, 316 p.

3. Dudov A.S. Social infrastructure of enterprises in modern conditions. URL: https://cyberleninka.ru/article/n/sotsialnayainfrastruktura-predpriyatiy-v-sovremennyhusloviyah

4. Kalicheva N.E., Ampilogov M.K. (2018) Influence of social responsibility on the effective development of railway transport enterprises. Problems of systematic approach in economy. Vol. 2, pp. 53-57.

5. Kompaniets V.V. (2016) Social Responsibility on Ukrainian Railways: Assessing the Impact of Reform and the Supply Mechanism. Bulletin of Economics of Transport and Industry. No. 55. - pp. 151161

6. Root MV Social development of the staff of PJSC "Ukrainian Railways" in the context of industry reform: implications and elements of provision. URL: https://cyberleninka.ru/article/n/sotsialniyrozvitok-kolektivu-pat-ukrayinskazaliznitsya-v-umovah-reformuvannya-galuzinaslidki-ta-elementi-zabezpechennya

7. Kryuchkov M.T., Konov A.A. Development of socio-cultural infrastructure of railway transport in the Urals. URL: https://www.fundamental-

research.com/issue/view?id=498

8. Kuchin S.P. The Essence and Dynamics of the Development of SocioCultural Infrastructure in Ukraine as an

http://www.investplan.com.ua/pdf/1_2017/17 .pdf

9. Letunovskaya N.E. Social infrastructure of industrial enterprise and its importance in the system of personnel. URL: http://mmi.fem.sumdu.edu.ua/sites/default/fil es/mmi2014_1_259_269.pdf

10. Matvienko V.V.

Evaluation and prospects of development of the railway industry in Ukraine. Public Administration: Improvement and Development. $\quad$ Vol. $8 . \quad$ URL: http://www.dy.nayka.com.ua/?op=1\&z=994

11. Tymoshenko M.M. (2014) Theoretical bases of development of social infrastructure of rural territories. Effective Economics. Vol. 11. - URL: http://www.economy.nayka.com.ua/?op=1\&z $=3501$

12. Tokarchuk D.M. The current state and prospects of development of social and industrial infrastructure of the village. URL:

http://econjournal.vsau.org/files/pdfa/241.pdf

13. Shashman AM The essence of social infrastructure of the enterprise and its impact on production efficiency. URL: http://www.rusnauka.com/9_DN_2010/Econ omics/62574.doc.htm

14. Shishin S.O.

Investigation of the general and special in the formation of social infrastructure of enterprises and administrative territories. Economics, Management, Finance: Materials V Intern. scientific Conf. (Krasnodar, August 2015). - Krasnodar: Innovation. pp. 114-118.

URL

https://moluch.ru/conf/econ/archive/204/8602 I 